\title{
PERANCANGAN SISTEM FILE ELEKTRONIK (E-FILLING) UNTUK UNIT PENGARSIPAN BALAI WILAYAH SUNGAI NUSA TENGGARA II
}

\author{
Gerlan A. Manu, ST, MKom \\ Sekolah Tinggi Keguruan dan Ilmu Pendidikan Citra Bina Nusantaral \\ Program Studi Pendidikan Teknologi Informasi \\ gerlanmanu@cbn.ac.id
}

\begin{abstract}
Abstrak
Arsip merupakan kumpulan dokumen yang disimpan secara teratur, terencana dan mempunyai suatu kegunaan pada setiap kali diperlukan dapat cepat ditemukan kembali. Pengelolaan Arsip di Balai Wilayah Sungai Nusa Tenggara II, menjadi tanggung jawab Kasubag Tata Usaha BWS NTII. Kondisi pengarsipan saat ini di Balai Wilayah Sungai Nusa Tenggara II yaitu arsip masih dikumpulkan secara fisik pada ruang arsip yang terbatas dengan lemari arsip yang juga terbatas, sehingga arsip belum tertata dan terdata dengan baik, dan juga belum optimalnya pengamanan arsip, terdapat arsip dinamis maupun arsip inaktif yang tercecer dan hilang. Balai Wilayah Sungai Nusa Tenggara II memandang perlu untuk mengoptimalkan penataan dan pengamanan arsip dengan Sistem E-Filling (Penyimpanan Elektronik). Pada penelitian ini, Sistem E-Filling (Penyimpanan Elektronik) dirancang untuk mampu menyimpan seluruh arsip Balai Wilayah Sungai Nusa Tenggara II, disamping itu sistem pun dapat mengamankan arsip sesuai dengan hak akses pada arsip tersebut, dan memudahkan pencarian arsip saat diperlukan.
\end{abstract}

Kata Kunci : Electronic File, Sistem Manajemen Arsip, Manajemen Kearsipan, Pengelolaan Arsip.

\section{PENDAHULUAN}

Pengarsipan merupakan cara penempatan arsip secara sistematis sehingga cepat ditemukan kembali saat diperlukan. Proses pengarsipan meliputi penerimaan arsip, penyimpanan (filling) dan penemuan kembali (finding), pemeliharaan, perawatan, pengamanan, pemindahan, penyerahan dan pemusnahan arsip.

Kondisi Pengarsipan di Balai Wilayah Sungai Nusa Tenggara II saat ini yaitu arsip masih dikumpulkan secara fisik pada Ruang Arsip, dengan Lemari Arsip yang masih terbatas. Dengan penataan dan pengelolaan arsip yang tidak dipantau baik oleh petugas arsip, maka banyak arsip yang tercecer dan hilang. Tidak optimalnya pemeliharaan, perawatan, dan pengamanan arsip mengakibatkan pada saat diperlukan arsip tidak cepat ditemukan. Oleh karena itu maka Balai Wilayah Sungai Nusa Tenggara II memandang perlu untuk mengoptimalkan penataan dan pengamanan arsip dengan Sistem E-Filling (Penyimpanan Elektronik). Diharapkan dengan adanya Sistem E-Filling dapat mengamankan pengaksesan arsip yang ada di Balai Wilayah Sungai Nusa Tenggara II. Terdapat beberapa arsip yang sifatnya dapat diakses publik dan juga terdapat arsip yang sifatnya hanya dapat diakses oleh kalangan tertentu saja. Dengan Sistem E-Filling ini semua arsip yang diterima oleh petugas arsip, dapat didata terlebih dahulu. Dan penempatan arsip pada lemari arsip, dapat didokumentasikan dan disimpan pada Sistem E-Filling, sehingga pada saatnya nanti jika diperlukan kembali, pencarian arsip dapat cepat ditemukan kembali. Dengan demikian maka, dengan adanya Sistem E-Filling ini akan sangat membantu 
Balai Wilayah Sungai Nusa Tenggara II dalam melakukan manajemen kearsipan.

\section{METODE PENELITIAN}

\subsection{WAKTU DAN TEMPAT PENELITIAN}

Penelitian ini dilakukan selama 3 bulan pada bulan Mei 2017 s/d Juli 2017. Tempat Penelitian adalah di Kantor Balai Wilayah Sungai Nusa Tenggara II yang bertempat di Jln. Frans Seda, Bundaran PU. Kota Kupang - NTT.

\subsection{METODE PENELITIAN}

Pada penelitian ini menggunakan metode penelitian SDLC (Systems Development Life Cycle) atau Siklus Hidup Pengembangan Sistem. Tahap-tahap penelitian menurut SDLC adalah sebagai berikut :

\section{Planning (Perencanaan)}

Peneliti melakukan observasi langsung dan wawancara terhadap Kasubab TU Balai Wilayah Sungai Nusa Tenggara II dan beberapa petugas arsip terkait pengarsipan di kantor Balai Wilaya Sungai Nusa Tenggara II. Dari hasil observasi dan wawancara ini ditemukan beberapa fakta-fakta yang menjadi latar belakang permasalahan pengarsipan di Balai Wilayah Sungai Nusa Tenggara II

2. Analysis (Analisis)

Berdasarkan fakta-fakta yang ditemukan maka peneliti dapat melakukan beberapa analisis yaitu : Analisis Teknologi dan Analisis Informasi.

a. Analisis Teknologi

- Balai Wilayah Sungai sudah memiliki website yang dapat diakses pada laman www.bwsnt2.org. Petugas Arsip dapat memanfaatkan web tersebut untuk mengunggah arsip yang sifatnya terbuka (dapat diakses oleh siapapun).

- Diperlukan database MySql yang akan digunakan untuk menyimpan data arsip yang diunggah. Database MySql dapat diakses secara online oleh petugas arsip, dan user lain yang berkepentingan.

- Diperlukan pembuatan Sistem Efilling sebagai interface sistem yang juga dapat diakses secara online oleh petugas arsip, dan user lain yang berkepentingan.

- Diperlukan integrasi antara Website Balai Wilayah Sungai Nusa Tenggara II dengan Sistem Efilling yang akan dirancang.

b. Analisis Informasi

- Diperlukan Data Petugas Arsip, Manajer Arsip dan Penanggung Jawab Arsip.

- Diperlukan SOP Pengelolaan Arsip pada Balai Wilayah Sungai Nusa Tenggara II

- Diperlukan Data Arsip sebagai contoh data untuk pengujian sistem.

3. Design (Desain)

Pada tahap ini peneliti melakukan desain Sistem Efilling dengan menggunakan Model DFD (Data Flow Diagram) dan desain Database yang digambarkan dengan Deskripsi Tabel dan Relasi Tabel.

4. Implementation (Implementasi)

Pada tahap ini peneliti mulai melakukan pengkodean (coding) dengan menggunakan Bahasa Pemrograman PHP untuk membuat Sistem Efilling berdasarkan Model DFD yang sudah dirancang sebelumnya. Dan peneliti juga membuat Database MySQL sesuai dengan desain Database yang telah dirancang pada tahap sebelumnya. 
5. Testing (Pengujian)

Pada tahap ini peneliti melakukan percobaan memasukan data contoh, dan menguji semua alur sistem yang sudah dibuat pada tahap implementasi. Jika ditemukan kesalahan pengkodean (error/bug) ataupun kesalahan logika maka akan kembali ke tahap sebelumnya yaitu tahap desain dan implementasi.

6. Maintenance (Perawatan)

Merupakan tahap akhir dalam pengembangan sistem. Perawatan atau Maintenance akan dilakukan jika sistem sudah digunakan oleh pengguna sistem (user), akan dilakukan perbaikan jika masih ditemukan kesalahan pengkodean (error/bug).

\section{HASIL DAN PEMBAHASAN}

\subsection{Profil Balai Wilayah Sungai Nusa Tenggara II}

Balai Wilayah Sungai Nusa Tenggara II merupakan wakil pemerintah pusat di daerah untuk melaksanakan pengelolaan SDA antara lain meliputi konservasi SDA, Pendayagunaan SDA, Pengendalian daya rusak air di Wilayah Sungai (WS) yang menjadi kewenangan pemerintah di Provinsi NTT yaitu WS Benanain, Noelmina dan Aesesa/Flores. (www.bwsnt2.org)

Struktur Organisasi Balai Wilayah Sungai Nusa Tenggara II tahun 2017

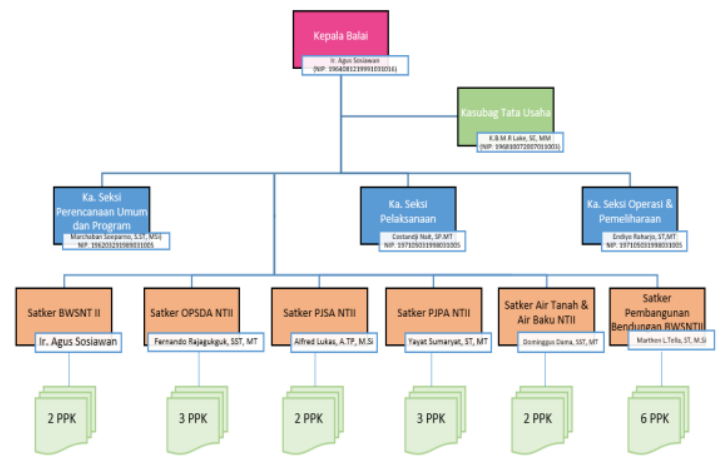

Gambar 1. Struktur Organisasi Balai Wilayah Sungai Nusa Tenggara II tahun 2017

Berdasarkan Peraturan Menteri PUPR No.20/PRT/M/2016 Pasal 67 ayat 1 Organisasi dan Tata Kerja Unit Pelaksana Teknis di Kementerian Pekerjaan Umum dan Perumahan Rakyat, dinyatakan bahwa pengarsipan menjadi salah satu tugas dari Kasubag Tata Usaha.

\subsection{ARSITEKTUR SISTEM}

Berikut adalah Arsitektur Sistem E-Filling :

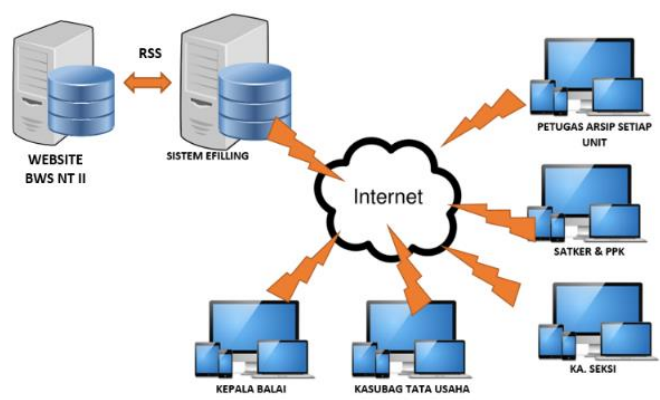

Gambar 2. Arsitektur Sistem E-Filling

Sistem E-Filling ini dapat diakses oleh setiap tingkatan unit dalam Struktur Organisasi

Balai Wilayah Sungai Nusa Tenggara II, secara online. Diketahui pada Website Balai Wilayah Sungai Nusa Tenggara II menyediakan teknologi RSS, sehingga pada Sistem E-Filling ini dapat menampilkan berita-berita terkini yang dipublikasikan pada website Balai Wilayah Sungai Nusa Tenggara II.

\subsection{DATA FLOW DIAGRAM}

Berikut adalah Bagan berjenjang yang menggambarkan proses sistem yang berjalan setiap levelnya : 


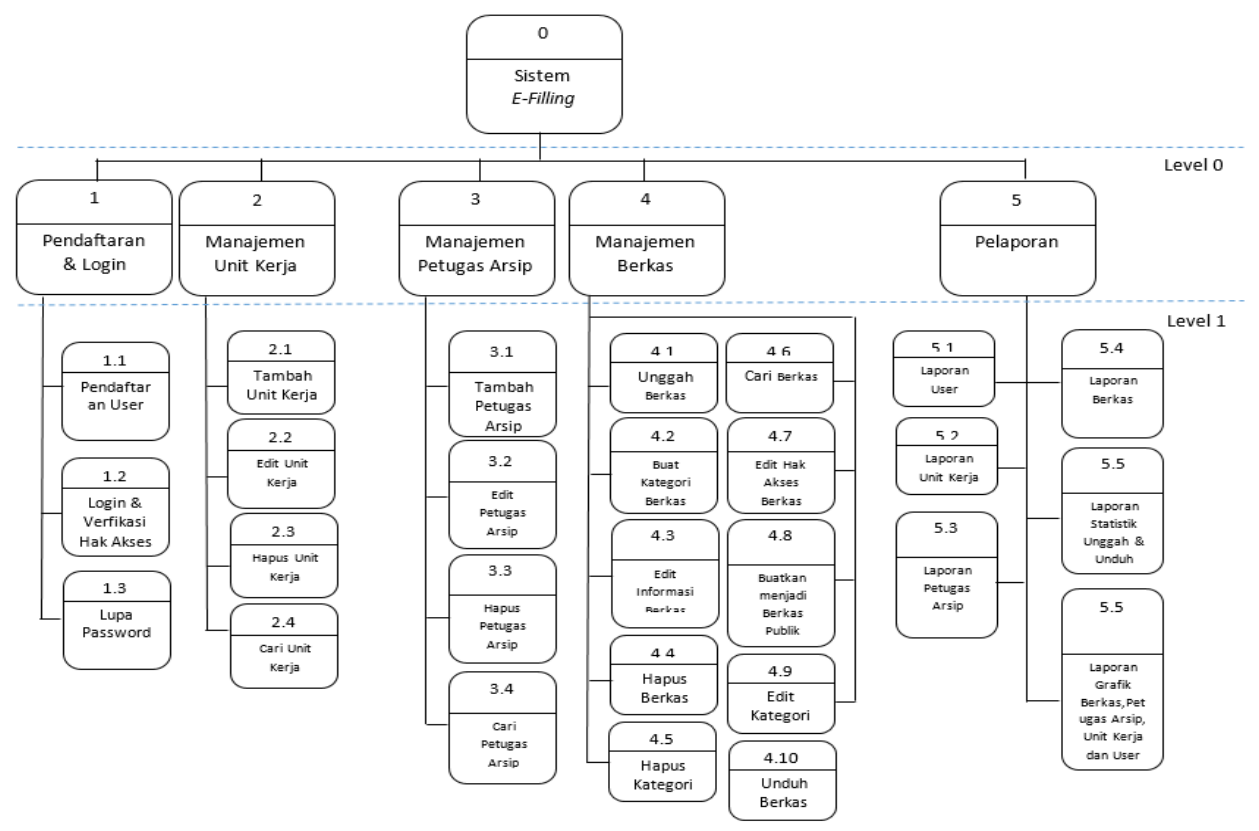

Gambar 3. Bagan Berjenjang Sistem E-Filling

Diagram Konteks, menampilkan alir data yang mengalir dari enam pengguna ke sistem, enam pengguna tersebut adalah Kepala Balai, Kabag TU, Ka Seksi, Satker \& PPK, Petugas Arsip dan Petugas Unggah Berkas Pimpinan, yang digambarkan sebagai berikut :

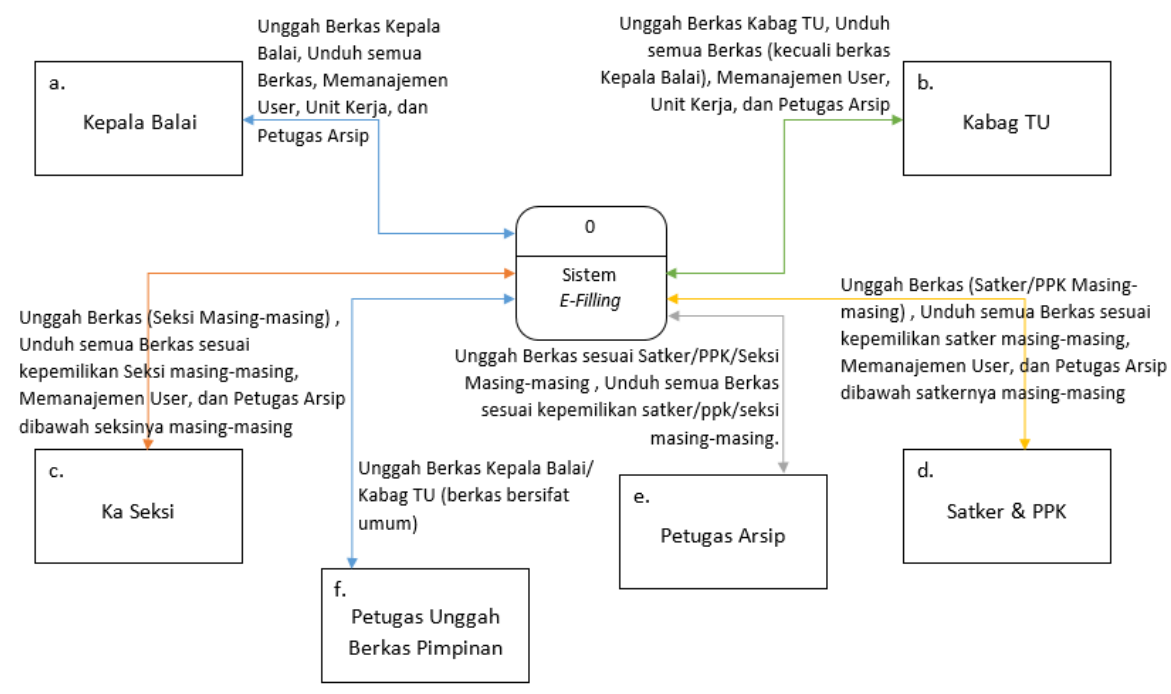

Gambar 4 Diagram Konteks Sistem E-Filling

Diagram Level 0, terdiri dari 5 buah proses, yaitu Proses Pendafaran \& Login, Proses Manajemen Unit Kerja, Proses Manajemen Petugas Arsip, Proses Manajemen Berkas, dan Proses Laporan yang digambarkan sebagai berikut : 


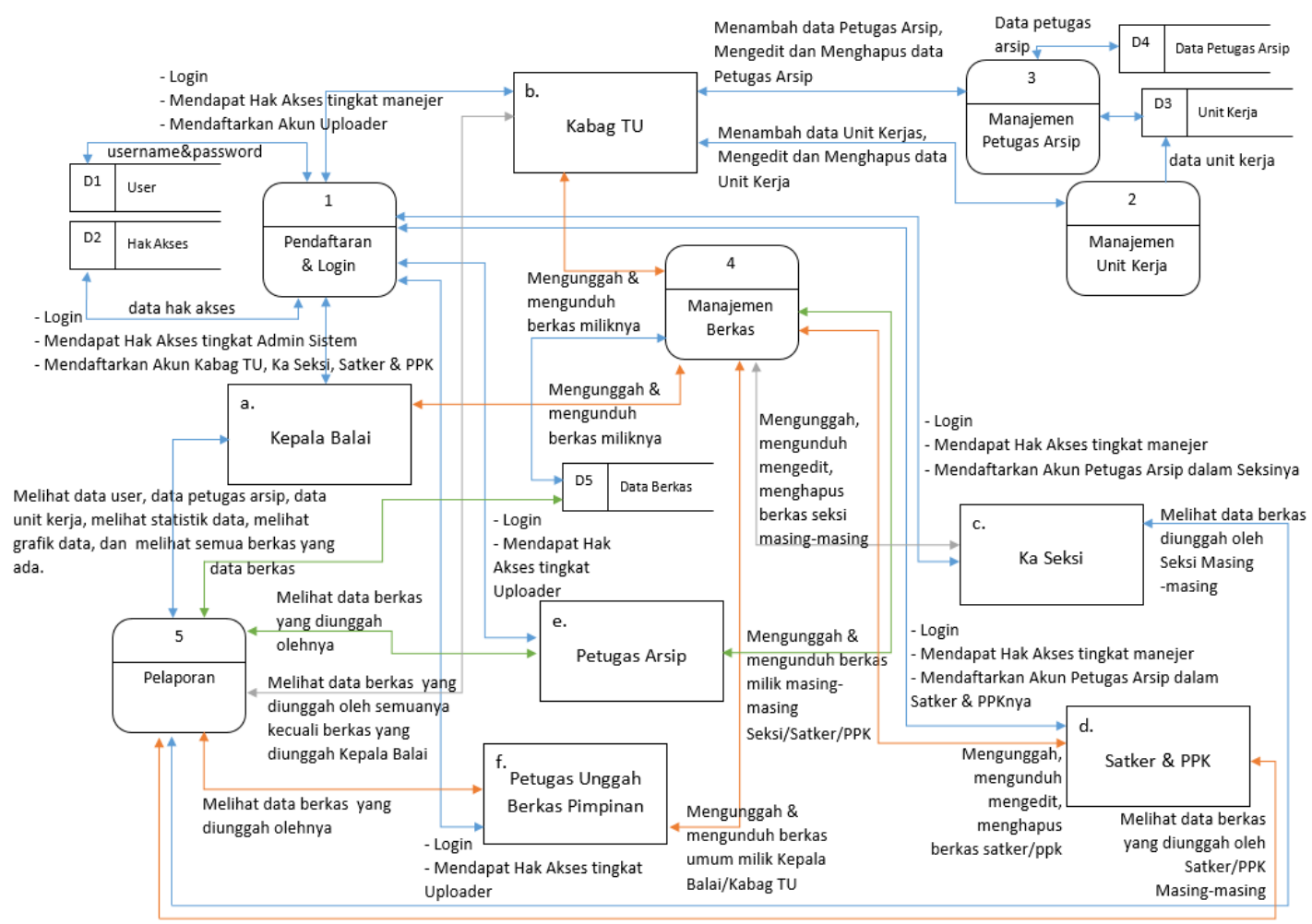

Gambar 5. Diagram Level 0 Sistem E-Filling

\subsection{RELASI TABEL}

Berikut adalah relasi tabel Sistem E-Filling yang dirancang :

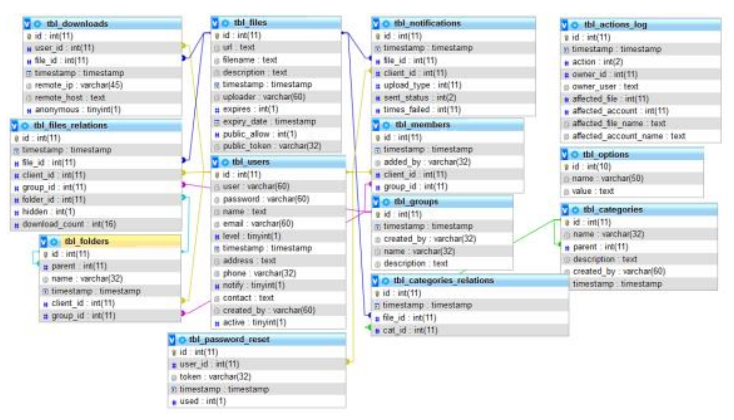

Gambar 6. Relasi Tabel Sistem E-Filling

\subsection{BISNIS PROSES}

\section{Proses Bisnis Pendaftaran Akun untuk mengakses Sistem E-Filling.}

Untuk masuk ke Sistem E-Filling, terdapat satu user yang sudah dibuatkan sebelumnya dan memiliki hak akses dengan level Administrator, yaitu user Kepala Balai. Kepala Balai bertugas untuk membuatkan user bagi Kabag TU, Ka. Seksi dan Satker masing-masing. Jenis user yang dibuatkan oleh Kepala Balai masing-masing akan memiliki hak akses dengan level Manejer. Kemudian Kabag TU akan membuat user bagi Petugas Unggah Berkas Pimpinan dengan hak akses level Uploader.

Tugas dari Petugas Unggah Berkas Pimpinan adalah mengunggah berkasberkas umum milik Kepala Balai, dan Kabag TU. Untuk berkas-berkas lainnya milik Kepala Balai dan Kabag TU yang memiliki keamanan berkas tertentu, misalnya hanya boleh diakses oleh Kepala Balai saja, akan diunggah langsung oleh Kepala Balai dengan akunnya.

Ka Seksi, dan Satker masing-masing yang memiliki hak akses dengan level Manejer, dapat membuat user bagi Petugas Arsip. Namun sebelumnya data petugas arsip ini perlu di tambahkan terlebih dahulu oleh Kabag TU. Hal ini karena Petugas Arsip perlu memiliki SK khusus yang tertera tugas dan tanggung jawab Petugas Arsip pada masing-masing Seksi dan Satker. 


\section{Proses Bisnis Lihat, Unggah dan Unduh Berkas pada Sistem E-Filling.}

Kepala Balai sebagai pimpinan tertinggi di Balai Wilayah Sungai Nusa Tenggara II memiliki akses penuh pada sistem $E$ Filling, sehingga Kepala Balai dapat melihat dan mengunduh berkas apapun yang ditambahkan pada sistem ini. Sedangkan Kabag TU dapat mengakses seluruh berkas yang ada kecuali berkas kepemilikan Kepala Balai.

Ka Seksi, dan Satker masing-masing hanya dapat mengakses berkas yang menjadi kepemilikan dari seksi atau satkernya masing-masing. Demikian juga dengan Petugas Arsip dan Petugas Unggah Berkas Pimpinan, hanya dapat mengakses berkas yang diunggahnya sendiri.

\subsection{TAMPILAN SISTEM E-FILLING}

Sistem E-Filling, ini dapat diakses secara online pada laman www.efilling.bwsnt2.org. Berikut adalah tampilan awalnya :

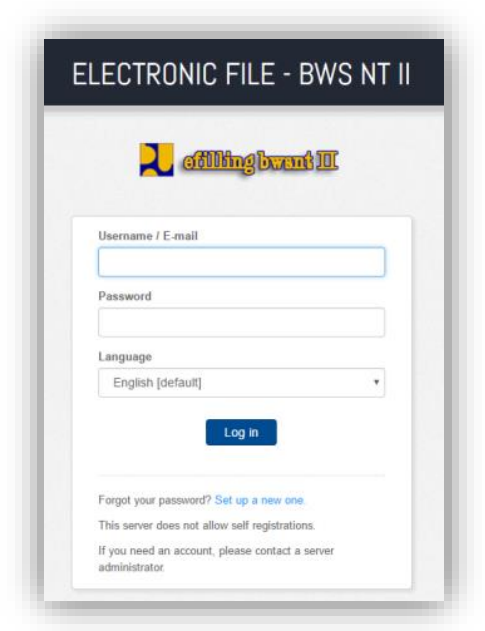

Gambar 7. Halaman Login Sistem EFilling

Berikut adalah tampilan Manajemen Berkas

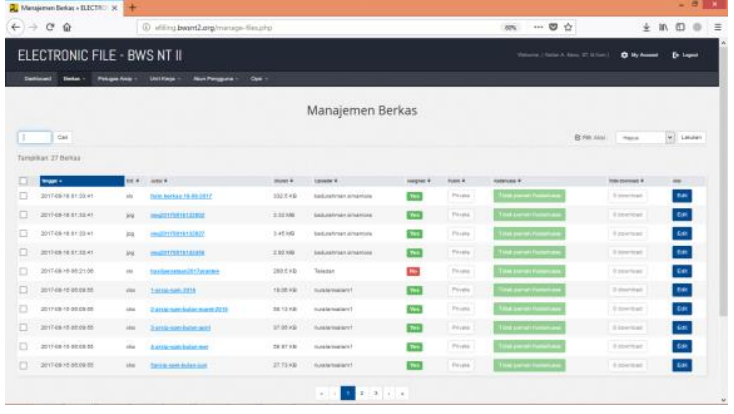

Gambar 8. Halaman Manajemen Berkas

Berikut adalah tampilan Edit Berkas, untuk salah satu file yang telah diunggah oleh Petugas Arsip :

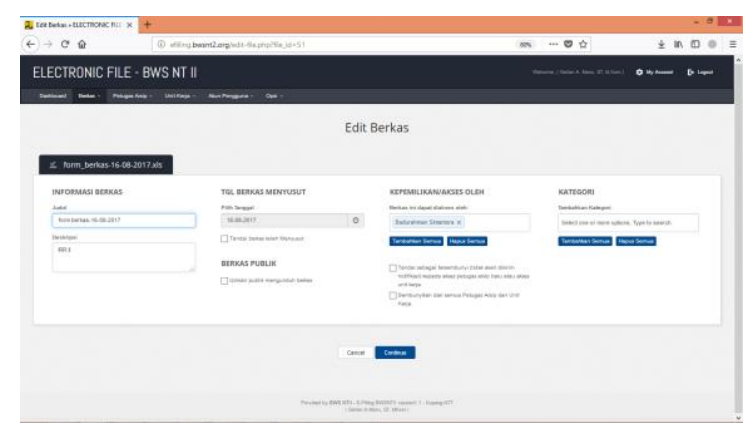

Gambar 9. Halaman Edit Berkas

Berikut adalah tampilan Manajemen Petugas Arsip :

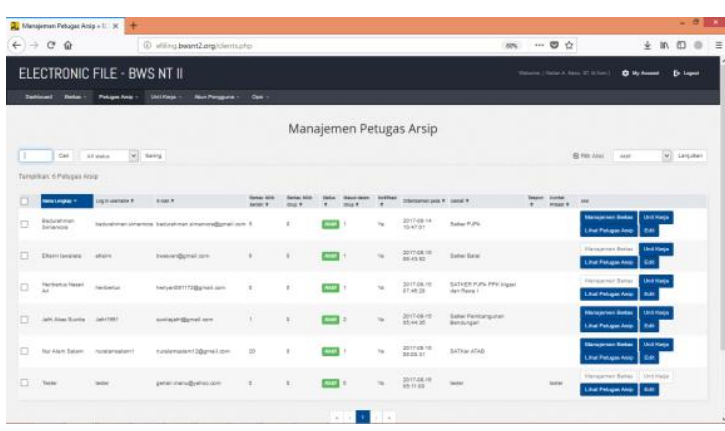

Gambar 10. Halaman Unit Kerja

Berikut adalah tampilan Manajemen Berkas milik salah satu Petugas Arsip : 


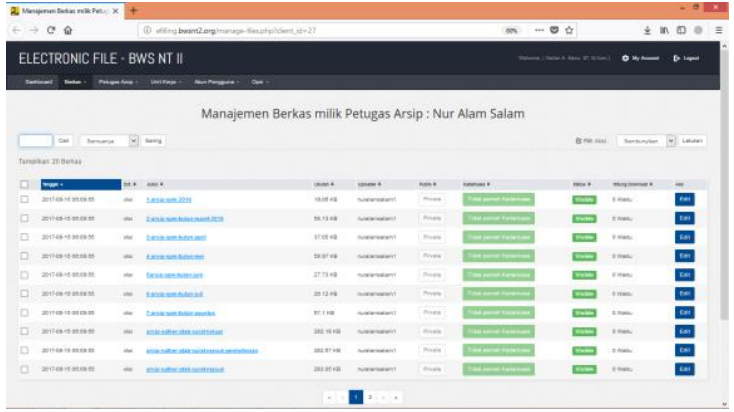

Gambar 11. Halaman Manajemen Berkas salah satu Petugas Arsip

Berikut adalah tampilan Manajemen Berkas dilihat dari hak akses seorang Petugas Arsip :

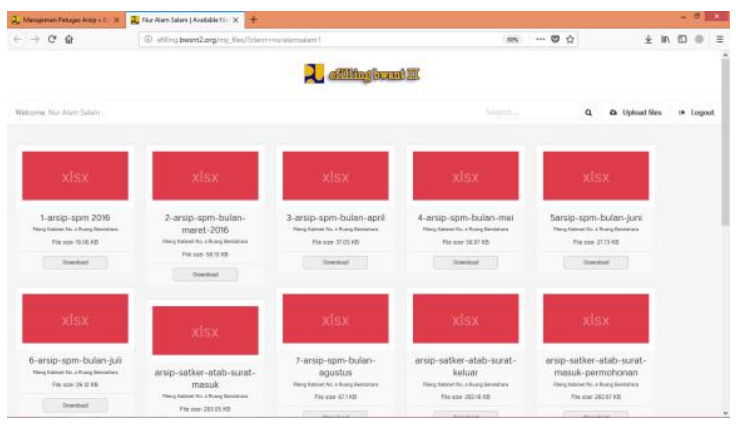

Gambar 12. Halaman Manajemen Berkas dilihat dari Hak Akses seorang Petugas Arsip

\section{KESIMPULAN}

Berdasarkan penelitian yang dilakukan maka peneliti dapat menyimpulkan beberapa hal sebagai berikut :

1. Sistem E-Filling ini hanya dapat diakses oleh pengguna internal Balai Wilayah Sungai Nusa Tenggara II.

2. Sistem E-Filling ini memiliki 3 level pengguna yaitu administrator, manejer, dan uploader.

3. Sistem E-Filling ini dibuat dengan menggunakan Framework Codeigniter

4. Sistem E-Filling ini menggunakan Database MySql
Adapun beberapa saran yang dapat disampaikan peneliti bagi penelitian selanjutnya yaitu :

1. Sistem dapat dikembangkan dengan menambahkan preview pada file/ berkas yang telah diunggah.

2. Pada penelitian selanjutnya dapat ditambahkan pemberitahuan atau notifikasi berkas yang baru diunggah oleh masing-masing Petugas Arsip.

\section{DAFTAR PUSTAKA}

[1] Amsyah Zulkifli. 2005. Manajemen Kearsipan. Jakarta. Penerbit : PT Gramedia Pustaka Umum

[2] Gaol, L, Jimmy. 2008. Sistem Informasi Manajemen Pemahaman dan Aplikasi. Jakarta : Penerbit PT Grasindo.

[3] Jogiyanto. 2005. Analisis \& Desain Sistem Informasi: Pendekatan Terstruktur, Teori dan Praktik Aplikasi Bisnis. Yogyakarta: CV Andi Offset.

[4] Kadir Abdul. 2014. Pengenalan Sistem Informasi. Yogyakarta : Penerbit ANDI

[5] Kadir Abdul. 2002. Konsep \& Tuntunan Praktis Basis Data. Yogyakarta : Penerbit ANDI.

[6] McLeod Jr Raymond, George P. Schell. 2007. Sistem Informasi Manajemen. Jakarta : Penerbit Salemba Empat.

[7] Nuraida Ida, SE. 2008. Manajemen Administrasi Perkantoran. Yogyakarta : Penerbit Kanisius. 